\title{
DIAGNOSTICS OF THE HEART CONDITION IN UKRAINIAN RIDING HORSES WITH A PORTABLE ECG MONITOR
}

B. V. POPADIUK, PhD student, Department of Therapy and Clinical Diagnosis https://orcid.org/0000-0001-7264-8410

S. I. HOLOPURA, Candidate of Veterinary Sciences, Associate Professor

Department of Therapy and Clinical Diagnosis

https://orcid.org/0000-0001-9149-0540

National University of Life and Environmental Sciences of Ukraine, Kyiv, Ukraine

E-mail: bogdana.popadiuk@nubip.edu.ua

\begin{abstract}
Electrocardiographic reference values of clinically healthy horses are needed for assessment of the reduced performance or cardiac pathology animals. The purpose of this study was to establish the rate of occurrence of arrhythmias in clinically healthy horses of the Ukrainian riding breed at rest, during exercises, and the recovery period. The experimental group of animals included 36 horses of age 3-17years, 16 mares (adult female horses), 11 geldings (castrated males), and 9 stallions (adult males). The electrodes were placed with a modified base-apex system on the surface of animals' bodies. ECG recording was performed at rest (15 minutes), during exercises and the recovery period for 30-40 and 15 minutes, respectively. Prevalence and frequency of occurrence of arrhythmias were analysed with obtained recordings. A significant number of the second-degree atrioventricular blocks were detected in $13.9 \%$ cases $(n=5)$ during the recovery period. $33.3 \%(n=2), 8.3 \%(n=3)$, and $19.4 \%$ $(n=7)$ of cases of supraventricular premature contractions were detected during exercises, at rest, and during the recovery period, respectively. The incidence of supraventricular premature contractions was < 3/animal and < 5/animal during exercises, and recovery period, respectively; with the exception of one animal in which 9 and 7 premature contractions were detected, respectively. Ventricular premature contractions were identified in $2.7 \%(n=1)$ and $5.6 \%(n=2)$ cases, at rest and exercises, respectively. Supraventricular tachycardia with 6-9 consecutive premature contractions during trot was detected in 1 horse (2.7\%). The results of this study have confirmed the presence of arrhythmias in clinically healthy horses. The type of arrhythmias significantly depends on the period (rest, exercises, and recovery) of the animal's activity, particularly.
\end{abstract}

Keywords: arrhythmias, heart condition diagnostics, portable ECG monitor, ECG records, horses 


\section{Introduction}

Electrocardiography is an indispensable and highly accurate method for diagnosing heart pathology, including arrhythmias. Any disorder in the cardiac impulse generation or conduction, changing the heart rhythm, causes an arrhythmia that can disrupt peripheral circulation. Electrocardiography is the most important method for diagnostics of arrhythmias (Alidady et al., 2002).

Arrhythmias are divided into two types: functional and organic. Arrhythmias of the first type are not associated with heart pathology, also called physiological or inorganic. For example, in horses and cattle, such arrhythmias can occur under the high influence of the autonomic nervous system. The second type, organic or pathological arrhythmias, is associated with heart disease or structural disorder in the cardiac conduction system (Dezfuli et al., 2001).

The value of electrocardiogram (ECG) in horses at rest is limited because most of the arrhythmias have a latent course and can occur only during the exercise. Furthermore, some disturbances in cardiac rhythm may appear after exercise during the recovery period (Young, 2007). In this case, for the complete diagnosis the ECG should be recorded not only at rest, but also during and after the exercise, especially in horses with a history of collapse.

\section{Analysis of recent researches and publications}

In 1911, Lewis recorded the first case of a pathological ECG of a horse with atrial fibrillation (Lewis, 1911). Since then many researchers, both foreign and domestic ones, have studied arrhythmias in horses.
Borovkov et al. (2013) studied the effect of age on the condition of the cardiovascular system in Ukrainian riding horses. They found that horses over 18 years old were more likely to have cardiac arrhythmias, namely sinoatrial and atrioventricular (AV) blocks.

Maksymovych studied the prevalence and significance of arrhythmias before and after exercise in athletic horses of Ukrainian riding, Hanoverian and Westphalian breeds. He reported that sinus arrhythmia (SA), second-degree AV block, and supraventricular premature complexes (SVPCs) were diagnosed with a high prevalence (Maksymovych, 2016).

Ryan et al. examined arrhythmias in apparently healthy Thoroughbred horses during and after exercises. The rate and prevalence of such arrhythmias as sinus arrhythmia, second-degree AV block, SVPCs, and ventricular premature complexes (VPCs) were established in their research (Ryan et al., 2005). Another research conducted by Buhl et al. investigated prevalence of arrhythmias before, during, and after exercises in clinically healthy show jumping horses of different breeds (Buhl et al., 2010).

The Ukrainian Riding Horse, or Ukrainian Saddle Horse, also known as Ukrainian Warmblood, is a relatively young Ukrainian breed of warmblood sport horses. Breeding of these horses has begun since 1945 and the genetic base constituted Hanoverian, Thoroughbred, and Trakehner stallions with local mares or Hungarian Furioso, Gidran Arab, or Nonius mares (Edwards, 2016). It was bred as show jumping, dressage and three-day eventing breed, but also suitable as a general riding horse (Rousseau et al., 2017).

Due to the lack of literature describing cardiac arrhythmias in Ukrainian riding horses during the exercises, the 
clinical significance of heart rhythm disturbances is yet to be established.

Purpose. The aim of this study was to document the incidence of arrhythmias in clinically healthy horses of the Ukrainian riding breed. The electrocardiography was performed in horses at rest, during exercises and the recovery period.

\section{Materials and methods of research}

The study was conducted in equestrian sport complexes and private stables in Kyiv region of Ukraine ("Kentaur", "Pavlovsky Passage", "Rodeo", "KSK Koenig", "Kyivska Rus", and others).

In order to confirm the clinically healthy condition of the animals and to form the experimental group, a physical examination was carried out, which included: anamnesis collection, rectal temperature measurement, examination of visible mucous membranes (conjunctiva of the eyes), determination of capillary refill time, apex beat (precordial area), arterial pulse (maxillary and digital arteries), and cardiac auscultation. Animals with clinical signs of oedema and the presence of heart murmurs were not included in the experimental group.

Animals. The experimental group of animals have included 36 horses at age of 3-17 years, 16 mares (adult females), 11 geldings (castrated males), and 9 stallions (adult males). 10 horses competed in dressage, 9 - in show jumping, 17 - did not take part in competitions, but 3-4 times a week had a general lungeing training.

$E C G$ recording. The ECG registration in Ukrainian riding horses was performed using a portable ECG monitor [a portable ECG monitor developed by scientists of the National Technical University of Ukraine "Kyiv Polytechnic
Institute named after Igor Sikorsky"]. With this purpose the system of 4 electrodes was placed as follows: the negative (red) electrode was attached on the right in front of the scapula, the positive (green) one - on the left directly behind the area of apex beat caudally from the elbow, the positive-negative (yellow) one $-5-10 \mathrm{~cm}$ above the green, and the reference (black) electrode - on the left in the area of the scapula (Popadiuk \& Holopura, 2020). Disposable electrode pads with a gel layer and a sticky base [SKINTACT F - 55, Innsbruck, Austria] were used. For better contact and stability of the electrodes during movement, a girth covering all electrodes was used. The ECG recordings were stored on a memory card of the device with the subsequent uploading to the cloud storage.

Exercises. The outdoor training was performed during spring and fall, in the morning with the temperature approximating to be $13-20{ }^{\circ} \mathrm{C}$. ECG recording in horses was performed in three stages:

1) at rest before exercise for $10-15$ minutes.

2) during physical activity for $30-40$ minutes.

3 ) during the recovery period immediately after exercise for 15 minutes.

The stage of physical activity included the warm-up and the exercise itself. The training protocol consisted of 7 intervals: 2 at a walk, 2 in trot, 2 in canter and 1 in a gallop. Each of the intervals lasted 3-10 minutes with a distance of 2000-4000 meters.

ECG analysis. Arrhythmias diagnostics was based on the following principles:

- second-degree AV block: the absence of the QRS complex for the $\mathrm{P}$ wave on the interval between the two previous P-P intervals. There are two types distinguished: 
physiological Mobitz type I with Wenckebach periods, when the PR interval gradually lengthens before the block, and pathological Mobitz type II, in which the P-R interval has a constant duration (Hilwig, 1977).

- sinus arrhythmia: variability of R-R intervals, in which the heart rate (HR) for several heartbeats decreases, increases, and decreases again, until a more stable rhythm is established (Menzies-Gow et al., 2001).

- sinus pause: increasing of the R-R interval by $20 \%$ at rest and by $10 \%$ during exercise; the $\mathrm{P}$ waves have a normal configuration (Ulfberg \& Clark, 2006).

- sinus block: the absence of the P wave for a time equal to the duration of the double previous P-P interval (Bonagura \& Miller, 1985)

- SVPCs: decreasing of the P-P interval by $20 \%$ at $\mathrm{HR}<60$ beats/min (bpm), by $10 \%$ at $\mathrm{HR}$ of $60-100 \mathrm{bpm}$, and by $4 \%$ at HR $>100 \mathrm{bpm}$; the morphology of the $\mathrm{P}$ wave may vary depending on the site of the impulse origin; premature contraction may be accompanied by a compensatory pause (Flethoj et al., 2016).

- supraventricular tachycardia (SVT): a series of three or more consecutive SVPCs.

- (VPCs: shortening of the R-R interval by more than $20 \%$; there is no $\mathrm{P}$ wave before the QRS complex; the QRS complex has an abnormal configuration (Buhl et al., 2010).

Statistical analysis. Descriptive analysis included determining the prevalence and frequency of arrhythmias, as well as the mean and $95 \%$ confidence intervals for the HR at three periods of each individual (rest, exercises, and recovery). Statistic data analysis was performed by two-way analysis of variance
(ANOVA) with such factors as arrhythmias and periods (rest, exercises, recovery) in the SAS software [SAS University Edition, NC, USA]. The results were considered significant at $\mathrm{P}<0.05$.

\section{Results of the research and their discussion}

The minimum and maximum HR for different periods (rest, exercises, and recovery) are shown in Fig. 1. The maximum HR during the gallop averaged 180-200 bpm.

ECG recordings (Fig. 2) are demonstrating sinus pause, sinus block, second-degree AV block, SVPCs, VPCs, and SVT. The prevalence and frequency of arrhythmias are shown in Table 1. The second-degree AV block was detected in $5(13.9 \%)$ horses during the recovery period. The prevalence and frequency of SVPCs and VPCs in individuals are shown in Table 2. In 12 animals $(33.3 \%)$ the SVPCs were detected during exercise, and in $3(8.3 \%)$ and $7(19.4 \%)$ at rest and during the recovery period, respectively. The incidence of SVPCs was $<3$ /animal during exercise, and $<5 /$ animal during the recovery, except for one animal, in which 9 and 7 premature contractions were detected, respectively. VPCs were identified in $2.7 \%(\mathrm{n}=1)$ and $5.6 \%(\mathrm{n}=2)$ cases at rest and exercises, respectively. SVT with 6-9 consecutive premature contractions during trot was detected in 1 horse $(2.7 \%)$.

ANOVA included sinus pause, sinus arrhythmia, second-degree AV block, and SVPCs. The remaining arrhythmias were not included in the analysis because of the insufficient sample. A significant relation $(\mathrm{P}<0.0001)$ between arrhythmias and different periods (rest, exercises, recovery) was found, con- 


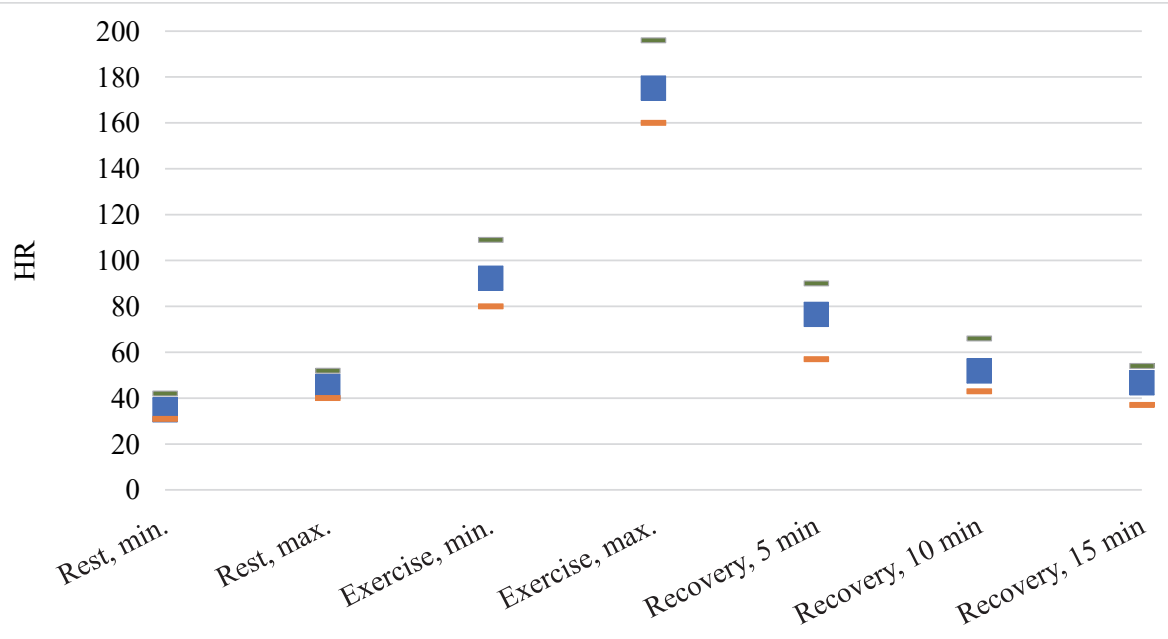

Fig. 1. The range of minimum, maximum values, and mean HR calculated for three periods (rest, exercises, and recovery, after 5, 10, and 15 minutes) of each individually. The error bars reflect the $95 \%$ confidence intervals

firming the fact that the type of arrhythmia varies depending on the period of activity or rest of the animal. During the exercise, an increase in the number of sinus arrhythmias $(\mathrm{P}=0.006)$ and SVPCs $(\mathrm{P}<0.0001)$, and during the recovery - an increase in the number of the second-degree AV block $(\mathrm{P}<0.0001)$ was found.
A. Sinus pauses on the ECG of a 7-year-old gelding on a walk. The beat after the pause is marked with a filled arrow. $\mathrm{HR}=50 \mathrm{bpm}$, Speed $=25 \mathrm{~mm} / \mathrm{s}$, $1 \mathrm{mV}=10 \mathrm{~mm}$

B. Sinus block on the ECG of a 5-yearold mare during the recovery period. The pause is equal to two R-R intervals. $\mathrm{HR}=$ $35 \mathrm{bpm}$, Speed $=25 \mathrm{~mm} / \mathrm{s}, 1 \mathrm{mV}=10 \mathrm{~mm}$
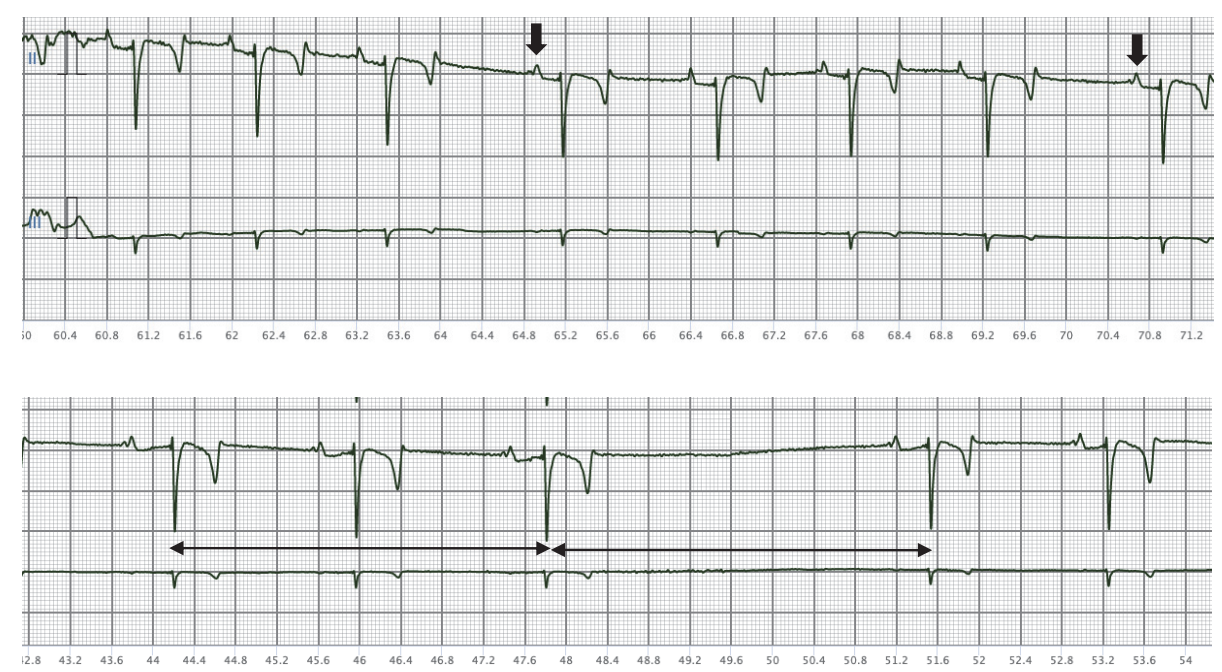


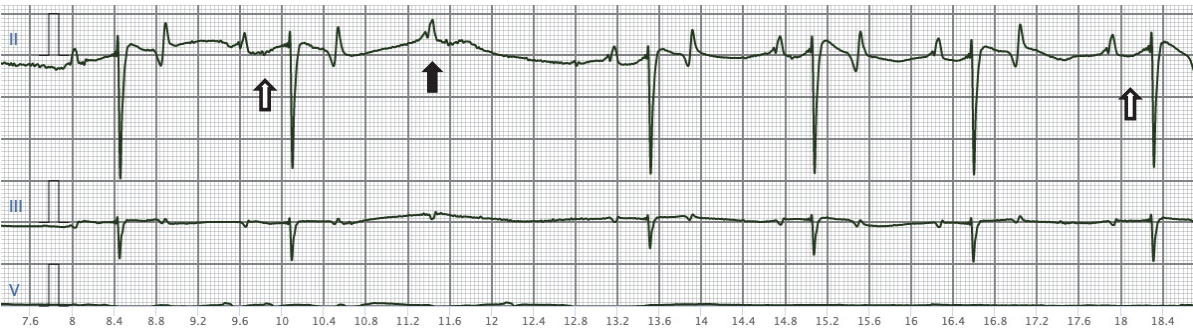

C. Second-degree AV block on the ECG of a 12-year-old mare during the recovery period. The blocked $\mathrm{P}$ wave is marked with a filled arrow. Some P-R intervals have a longer duration - Wenckebach phenomenon, marked with an empty arrow. $\mathrm{HR}=31$ $\mathrm{bpm}$, Speed $=25 \mathrm{~mm} / \mathrm{s}, 1 \mathrm{mV}=10 \mathrm{~mm}$ double arrow). Also, premature $\mathrm{P}$ wave has clearly different morphology compared to normal $\mathrm{P}$ waves (empty arrow). $\mathrm{HR}=38$ $\mathrm{bpm}$, Speed $=25 \mathrm{~mm} / \mathrm{s}, 1 \mathrm{mV}=10 \mathrm{~mm}$

E. VPCs on the ECG of a 5-year-old stallion at rest. The premature contraction (filled arrow) has a bizarre mor-

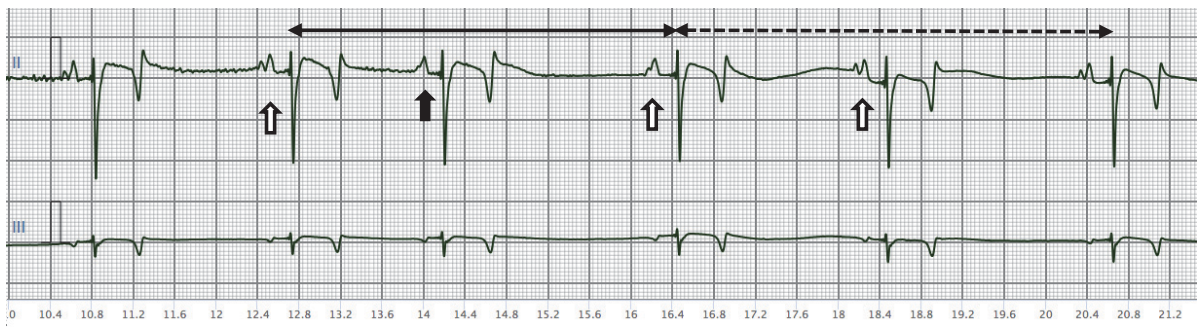

D. SVPCs on the ECG of a 7-year-old gelding at rest. The premature contractions (marked with a filled arrow) are followed by a noncompensatory pause, because the premature depolarization resets the sinus node, meaning that the R-R interval encompassing the SVPC (solid double arrow) is shorter than the normal R-R interval (dashed phology, longer QRS duration, and is followed by a $\mathrm{T}$ wave with the opposite direction. The subsequent $\mathrm{P}$ wave (empty arrow) occurs in predefined time but is blocked and followed by a compensatory pause due to the refractoriness of the ventricular myocardium. $\mathrm{HR}=39 \mathrm{bpm}$, Speed $=50 \mathrm{~mm} / \mathrm{s}, 1 \mathrm{mV}=20 \mathrm{~mm}$.

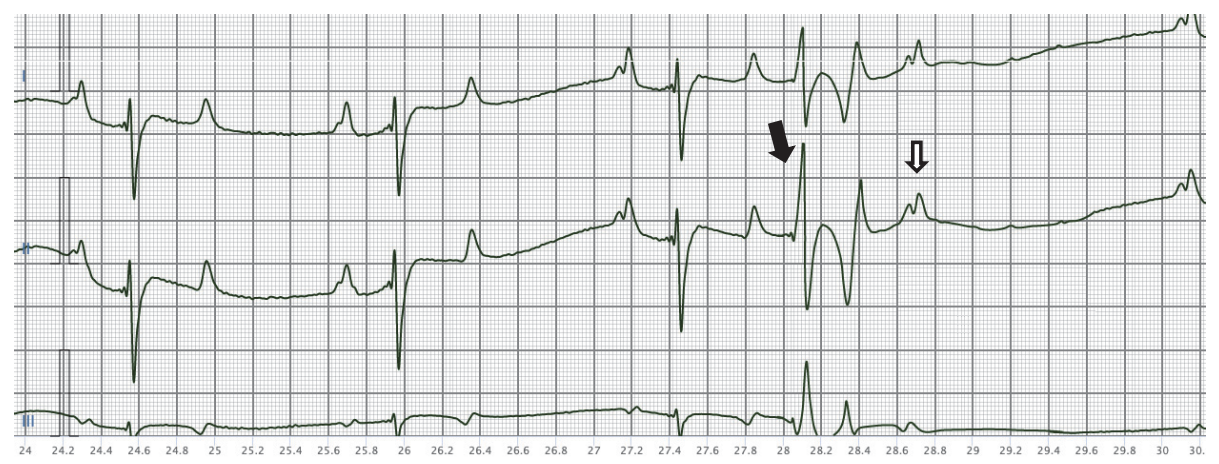


F. SVT on the ECG of a 9.5-year-old stallion during trotting. The atrial rate is about 75 bpm. The QRS complexes after premature P waves (marked with a filled arrow) show a larger amplitude and $\mathrm{T}$ waves have the opposite direction, which is often the case for short R-R interval. $\mathrm{HR}=68$ bpm, Speed $=25 \mathrm{~mm} / \mathrm{s}, 1 \mathrm{mV}=10 \mathrm{~mm}$.
Wenckebach phenomenon was present, so such arrhythmia was considered to be a physiological one.

Normally, horses may develop SVPCs both at rest and during the recovery. Frequent premature contractions during exercise, especially at the peak HR, are considered to be a consequence of atrial

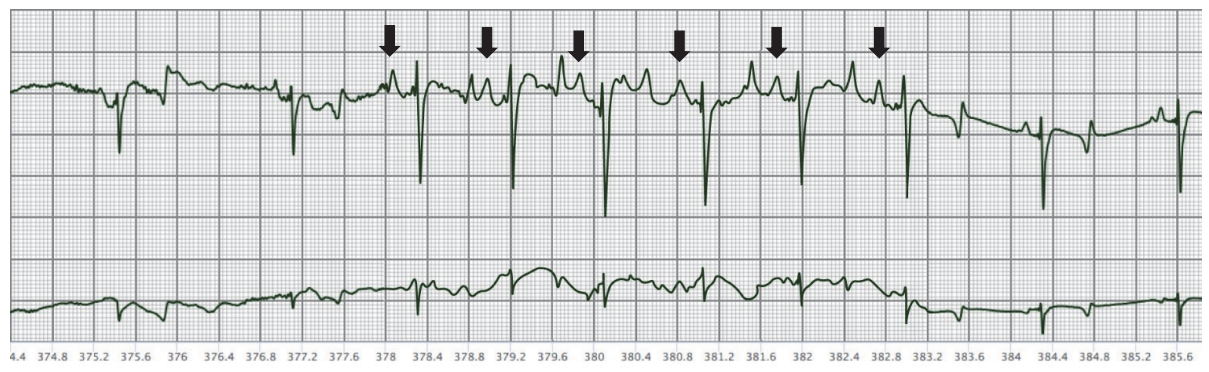

Fig. 2. ECG recordings with a sinus pause (A), sinus block (B), second-degree AV block (C), SVPCs (D), VPCs (E), and SVT (F)

For the first time, a detailed analysis of ECG for the presence of arrhythmias in Ukrainian riding horses before, during, and after the exercises was demonstrated.

Second-degree AV block, found in 6 animals (16.6\%), completely disappeared during exercise and in 5 animals $(13.9 \%)$ returned during the recovery period, when the HR decreased to the rest values. In all cases of diagnosis of this arrhythmia, the myocardial disease. The number of animals in which SVPCs were detected, as well as the frequency of extrasystoles per animal, was lower in our study compared to the data obtained by other researchers in their studies (Ryan et al., 2005; Buhl et al., 2010). Nonetheless, most SVPCs occurred during the low intensity of exercise and low HR, which is consistent with data obtained by other researchers. It is note-

\section{Prevalence of detected cardiac arrhythmias in horses at rest, during exercises and the recovery period}

\begin{tabular}{|l|c|c|c|}
\hline \multirow{2}{*}{\multicolumn{1}{c|}{ Arrhythmia }} & \multicolumn{3}{|c|}{ Type of horse work } \\
\cline { 2 - 4 } & Rest $(\mathrm{n}, \%)$ & Exercises $(\mathrm{n}, \%)$ & Recovery $(\mathrm{n}, \%)$ \\
\hline Second-degree AV block & $6(16.6)$ & $1(2.7)$ & $5(13.9)$ \\
\hline SVPCs & $3(8.3)$ & $12(33.3)$ & $7(19.4)$ \\
\hline SVT & - & $1(2.7)$ & - \\
\hline Sinus block & - & - & $2(5.6)$ \\
\hline Sinus arrhythmia & $4(11.1)$ & $10(27.8)$ & $6(16.6)$ \\
\hline VPCs & $1(2.7)$ & $2(5.6)$ & - \\
\hline Sinus pause & $2(5.6)$ & $3(8.3)$ & $5(13.9)$ \\
\hline Sinus tachycardia & $1(2.7)$ & - & $1(2.7)$ \\
\hline
\end{tabular}


worthy that no extrasystoles were detected during peak exercise, so its occurrence might be explained by the fluctuations in HR due to the changes in the pace and the influence of the autonomic nervous system on the equine heart.

VPCs are the result of a violation of electrical activity in the heart ventricles, resulting in premature contraction (Bonagura \& Miller, 1985). The value of ventricular arrhythmias for animals often contradicts each other, but its occurrence is usually associated with myocardial disease (Reimer et al., 1992). Ventricular extrasystoles in the current study occurred at a higher HR (110-130 bpm) compared with SVPCs (45-90 bpm).

Single VPCs that occur at the end or immediately after the exercises, in the absence of structural myocardial disease, are considered to be physiological ones (Reef et al., 2014). In case if $>2$ SVPCs or VPCs occur at peak loads, or $>5$ pairs during the recovery period, its presence may cause poor performance, predispose to the development of ventricular tachycardia, and even collapse and sudden death (Martin et al., 2000). However, recent studies in clinically healthy horses, with significantly exceeding numbers of SVPs and VPCs, have questioned the validity of these cut-off values. The current study revealed fewer VPCs than in the studies of other authors, which may be explained by the different protocols of the exercise procedure (Ryan et al., 2005; Buhl et al., 2010; Maksymovych, 2016).

\section{The number of SVPSs, VPCs, and SVT at rest, during recovery and exercises in horses, with periods specified}

\begin{tabular}{|l|c|c|c|c|c|c|c|}
\hline \multirow{2}{*}{ № } & \multirow{2}{*}{$\begin{array}{c}\text { Age, } \\
\text { years }\end{array}$} & $\begin{array}{c}\text { Physiological } \\
\text { condition of male } \\
\text { and female }\end{array}$ & \multicolumn{2}{|c|}{ Rest and recovery } & \multicolumn{3}{|c|}{ Exercises } \\
\cline { 4 - 9 } & & SVPCs & VPCs & SVPCs & VPCs & SVT \\
\hline 1 & 4 & M & 3 rest & - & 1 trot & - & - \\
\hline 2 & 5 & S & - & 1 rest & - & 1 canter & - \\
\hline 3 & 5.5 & M & $\begin{array}{c}2 \text { rest, } 7 \\
\text { recovery }\end{array}$ & - & $\begin{array}{c}5 \text { walk, } \\
\text { trot }\end{array}$ & - & - \\
\hline 4 & 6 & G & - & - & 1 walk & - & - \\
\hline 5 & 7 & M & - & - & 1 walk & - & - \\
\hline 6 & 7 & G & $\begin{array}{c}2 \text { rest, } 5 \\
\text { recovery }\end{array}$ & - & 3 walk & - & - \\
\hline 7 & 7 & S & - & - & 2 trot & - & - \\
\hline 8 & 7.5 & M & 3 recovery & - & 1 canter & - & - \\
\hline 9 & 8 & M & 2 recovery & - & 1 trot & - & - \\
\hline 10 & 9 & G & - & - & 1 trot & - & - \\
\hline 11 & 9.5 & S & - & - & - & - & 2 trot \\
\hline 12 & 11 & M & - & - & 1 walk & 1 canter & - \\
\hline 13 & 12 & G & 1 recovery & - & 2 walk & - & - \\
\hline 14 & 13 & M & $\begin{array}{c}1 \text { rest, } 1 \\
\text { recovery }\end{array}$ & - & 2 trot & - & - \\
\hline
\end{tabular}

Note: $\mathrm{M}$ - mare, $\mathrm{G}$ - gelding, $\mathrm{S}$ - stallion. 
SVT in most cases is pathological and occurs due to myocardial disease, atrial dilatation, or another congenital heart disease. Subsequently, SVT may lead to the development of atrial fibrillation (Marr \& Bowen, 2010). In our study, it was detected in 1 animal and was manifested as 6 and 9 consecutive SVPCs.

The sinus pauses found in the current study have been previously described (Buhl et al., 2010). This arrhythmia was diagnosed during a walk or trot of the animal, and on the ECG, it is visually similar to a sinus block with a shorter duration. It can be assumed that sinus pauses occur during the return to vagal tone, resulting in a slight delay in the impulse conduction through the sinus node. Since the high vagal tone is typical for horses, the sinus pauses may be considered a physiological arrhythmia.

\section{Conclusions and future perspectives of the study}

As per our present study, it was clearly shown that usage of the portable ECG monitor confirms arrhythmias in clinically healthy horses of the Ukrainian riding breed. It was found that the type of arrhythmia significantly depends on the period (rest, exercises, and recovery) of their activity.

The second-degree atrioventricular block was most often $(16.6 \%)$ registered at rest. During the exercises most frequently (33.3\% of cases) supraventricular premature complexes develop, in particular, in most cases, premature contractions occur at a relatively low heart rate and low intensity of exercises.

The obtained reference values allow the veterinarians to assess the heart functions in horses of Ukrainian riding breed with poor performance, clinical signs of cardiac pathology, or cases of collapse in the case report.

\section{References}

Alidady, N., Dezfouki, M. R. \& Nadalian, M. G. (2002). The ECG of Turkman horse using the standard lead base apex. Veterinary Science, 22(5):182-184.

Bonagura, J. D. \& Miller, M. S. (1985). Junctional and ventricular arrhythmias. Journal of equine veterinary Science, 5:347-350.

Borovkov, S., Korenev, M. \& Borovkova, V. (2013). Functional condition of cardiovascular system in horses of Ukrainian up-river breed depending on age. Scientific journal of veterinary medicine, 11(101):22-25. (in Ukrainian)

Buhl, R., Meldgaard, C. \& Barbesgaard, L. (2010). Cardiac arrhythmias in clinically healthy showjumping horses. Equine veterinary journal, 42:196-201.

Edwards, E. H. (2016). The Encyclopedia of the Horse. DK Publishing, 360.

Flethoj, M., Kanters, J. K. \& Pedersen, P. J. (2016). Appropriate threshold levels of cardiac beat-to-beat variation in semi-automatic analysis of equine ECG recordings. BMC Veterinary Research, 12:266.

Hilwig, R. W. (1977). Cardiac arrhythmias in the horse. Journal of the American Veterinary Medical Association, 170:153-163.

Lewis, T. (1911). Irregularity of the heart's action in horses and its relation to fibrillation of the auricles in experiment and to complete irregularity of the human heart. Heart, 3:161.

Maksymovych, I. (2016). Prevalence and diagnosis of cardiac arrhythmias in sport horses. Scientific journal of veterinary medicine, 2:57-63. (in Ukrainian)

Marr, C. \& Bowen, M. (2010) Cardiology of the Horse, 2nd Edition. London, Elsevier, 320.

Martin, B. B., Reef, V. B. \& Parente, E. J. (2000). Causes of poor performance of horses during training, racing, or showing: 348 cases (19921996). Journal of the American Veterinary Medical Association, 216:554-558.

Menzies-Gow, N. (2001). ECG interpretation in the horse. In Practice, 9:454-459. 
Mokhber Dezfuli, M. R., Alidady, N. \& Nadalian, M. G. (2001). The characters of QRS complex in the ECG of Torkman (saka) horse. Journal of faculty of Veterinary medicine University of Tehran., 56(1):7-12.

Popadiuk, B. \& Holopura, S. (2020). Validation of a portable ECG monitor for the diagnosis of arrhythmias in horses compared to a standard electrocardiograph. Scientific Messenger of Lviv National University of Veterinary Medicine and Biotechnologies. Series: Veterinary sciences, 22(97):20-25.

Reef, V. B., Bonagura, J. \& Buhl, R. (2014). Recommendations for management of equine athletes with cardiovascular abnormalities. The Journal of Veterinary Internal Medicine; 28(3):749-61.

Reimer, J. M., Reef, V. B. \& Sweeney, R. W. (1992). Ventricular arrhythmias in horses -21 cases
(1984-1989). Journal of the American Veterinary Medical Association, 201:1237-1243.

Rousseau E., Bris Y. L. \& Fagan T. L. (2017). Horses of the World. Princeton, Princeton University Press, 528.

Ryan, N., Marr, C. M. \& McGladdery, A. J. (2005). Survey of cardiac arrhythmias during submaximal and maximal exercise in Thoroughbred racehorses. Equine Veterinary Journal, 37:265-268.

Ulfberg, J. W. \& Clark, J. S. (2006). Bradydysrhythmias and atrioventricular conduction blocks. Emergency Medicine Clinics of North America., 24:1-9.

Young, L. E. (2007). Recent advances in diagnosing cardiac abnormalities with an ECG during exercise: a659847 review. Proceedings of the American Association of Equine Practitioners, 53:99-103.

\section{Б. В. Попадюк, С. І. ГоЛопУра (2020). ДІАГНОСТИКА СТАНУ СЕРЦЯ КОНЕЙ УКРА- ÏНСЬКОЇ ВЕРХОВОЇ ПОРОДИ ПОРТАТИВНИМ ЕКГ-МОНІТОРОМ. Ukrainian Journal of Veterinary Sciences, 11(4): 4-13, https://doi.org/10.31548/ujvs2020.04.001}

Анотачія: Електрокардіографічні референтні значення клінічно здорових коней є необхідними під час оцінки коней зі зниженою продуктивністю або серцевими патологіями. Метою цього дослідження було встановити частоту виникнення аритмій у клінічно здорових коней українськоі верхової породи в стані спокою, під час фізичних навантанень та у період відпочинку. Дослідна група включала 36 коней української верхової породи віком від 3 до 17 років - 16 кобил (дорослі самки), 11 меринів (кастровані самці) та 9 жеребців (дорослі самиі). Електроди розмішували за модифікованою осново-верхівковою системою на тілі тварин. Реєстрацію ЕКГ проводили у стані спокою (15 хв), під час навантажень та у період відновлення відповідно впродовж 30-40 та 15 хв. На одержаних записах аналізували переважання та частоту виникнення аритмій. Значну кількість атріовентрикулярних блокад у 13,9\% ( $n=5)$ було виявлено у період після навантаження. 33,3\% ( $n=12), 8,3 \%$ ( $n=3), 19,4 \%$ ( $n=7)$ випадків суправентрикулярних екстрасистол було виявлено відповідно під час навантаження, у стані спокою та у період відновлення. Частота виникнення суправентрикулярних екстрасистол складала <3/тварину та <5/mварину відповідно під час навантаження та відновлення, окрім однієі тварини, у якої було виявлено відповідно 9 та 7 екстрасистол. Шлуночкові естрасистоли було виявлено у 2,7\% (n=1) та 5,6\% (n=2) відповідно у стані спокою та під час руху. Суправентрикулярну тахікардію з 6-9 послідовних екстрасистол під час руху риссю було виявлено у одного коня (2,7\%). Результати дослідження підтверджують наявність аритмій у клінічно здорових коней української верхової породи. Тип аритмії достовірно залежить від періоду (спокій, навантаження, відновлення) активності тварини.

Ключові слова: аритмії, діагностика стану серця, портативний ЕКГ-монітор, реєстрація ЕКГ, коні 